\title{
Epstein-Barr virus as a possible etiologic agent in primary central nervous system lymphoma in immunocompetent individuals
}

\author{
Ashwani Tandon, Sundaram Challa, M. Shanmugam, Swarnalatha Gopalan, Roshni T. Paul, \\ Raghunadharao Digumarthi \\ Department of Pathology, Nizam's Institute of Medical Sciences, Punjagutta, Hyderabad - 500 082. Andhra Pradesh, India
}

\author{
Address for correspondence: \\ Dr. C. Sundaram, \\ Department of Pathology, Nizam's \\ Institute of Medical Sciences, \\ Punjagutta, Hyderabad - 500082. \\ Andhra Pradesh, India. \\ E-mail: challa_sundaram@ \\ yahoo.com
}

DOI: $10.4103 / 0028-3886.48813$

\begin{abstract}
Abstrat
Background: Primary central nervous system lymphoma (PCNSL) occurs in both immunocompetent and immunosuppressed individuals. The role of Epstein-Barr virus (EBV) has been implicated in immunosuppressed individuals but its role is not established in immunocompetent individuals. Aims: To study the possible role of EBV in PCNSL in immunocompetent individuals. Setting and Design: Retrospective study. Materials and Methods: Thirty patients with PCNSL were studied immunohistochemically with antibodies to CD 45, CD 20, CD3 and EBV latent membrane protein-1 (EBV LM P-1). In situ hybridization was done in 19 patients where enough tissue was available using a specific oligonucleotide probe for EBV-Early RNA (EBER). Results: All the patients were immunocompetent and mean age was 41.6 years. Histologically they were diffuse large cell lymphoma: 25 (83.3\%) were B cell, 1(3.3\%) was T cell and $4(13.3 \%)$ were unclassified. EBV LMP-1 showed variable membrane and cytoplasmic positivity in 24 (80\%) patients. In situ hybridization for EBER was negative in all the 19 patients studied. Conclusion: In this region of the world probably EBV has no etiologic role in PCNSL in immunocompetent individuals.
\end{abstract}

Key words: Epstein-Barr virus, immunocompetent individuals, in situ hybrid ization, India, latent membrane protein-1, primary central nervous system lymphoma

\section{Introduction}

Primary central nervous system lymphoma (PCNSL) can occur in both immunosuppressed and immunocompetent individuals. ${ }^{[1,2]}$ PCNSL in patients with acquired immuno-defieciency syndromes (AIDS) is etiologically related to Epstein-Barr Virus (EBV). ${ }^{[-6]}$ The etiology of PCNSL in immunocompetent individuals is uncertain. Majority of PCNSL reported from India are in immunocompetent individuals. ${ }^{[6-9]}$ Epidemiologic studies from India suggest EBV infection often occurs in younger age group. ${ }^{[10]}$ Studies from India reported a strong association between EBV and Hodgkin's lymphoma both in adults and children, especially with mixed cellularity type. ${ }^{[10]}$ We studied 30 immunocompetent patients with PCNSL immunohistochemically with antibodies to EBV latent membrane protein-1 (EBV LMP-1) and also in situ hybridization (ISH) using a specific oligonucleotide probe for EBV-early RNA (EBER) to determine possible etiological relationship between EBV and PCNSL.

\section{Materials and M ethods}

Patients with histologically confirmed PCNSL seen in two tertiary care hospitals between January 1988 and April 2003 were the subjects of the study. Of these patients, only those patients where paraffin block 
were available were included. Patients with systemic lymphoma were excluded from the study. Age, gender, clinical features. and immunological and retroviral status of the patients were noted from the case records. Informed consent was obtained from all the patients at the time of surgical procedure.

Diagnosis of PCNSL was established by tissue morphology on the samples obtained by stereotactic or excisional biopsy by hematoxylin and eosin ( $\mathrm{H} \& \mathrm{E}$ ) and reticulin stains. Immunohistochemistry was performed by standard streptavidin biotin technique with horseradish peroxidase conjugate using antibodies against CD45, CD20 and CD3. Antigen was extracted using hightemperature antigen retrieval (pressure cooker) technique. Positive controls were sections from lymph node from patients with Hodgkin's lymphoma and negative controls were lymph node sections without primary antibodies. Immunohistochemistry for EBV LMP-1 was performed by avidin biotin complex method with trypsin digestion for antigen retrieval. All monoclonal primary antiobodies were of Novo castra (United Kingdom). Briefly, 5-micron paraffin sections were deparaffinized in xylene, dehydrated in graded alcohol series, and rinsed in tris buffer saline (TBS) (0.05 M, pH 7.6) for $15 \mathrm{~min}$. The sections were then microwaved for 15-20 min at 700 $\mathrm{W}$ in sodium citrate buffer (10 m M, $\mathrm{pH}$ 6.0) to retrieve antigen from paraffin sections. For LMP-1 staining, the sections were pretreated with $0.05 \%$ trypsin at $37^{\circ} \mathrm{C}$ for 30 $\mathrm{min}$. All sections were further treated with methanol and $3 \%$ hydrogen peroxide to block endogenous peroxidase followed by buffer. Three per cent milk powder or bovine serum albumin was used to block background staining for $30 \mathrm{~min}$. The sections were then incubated with the primary antibody for $2 \mathrm{~h}$ followed by biotinylated goat antimouse immunoglobulin antiserum (1: 50, DAKO, Denmark), which was used as the secondary antibody by the avidin-biotin peroxidase complex for 2 h. 3,3'-diaminobenzidine (Sigma, Germany) was used as the chromogenic substrate.

ISH was done in only 19 patients where enough tumor tissue was available. ISH was performed using a specific oligonucleotide probe (Novocastra - kit number NCLEBV-K, UK) which hybridizes EBV encoded RNA (EBER) transcripts concentrated in the nuclei of latently infected cells. Five-micron sections were mounted on APES-coated slides and were dewaxed and dehydrated. This was followed by 30 min digestion with proteinase $\mathrm{K}$ at $37^{\circ} \mathrm{C}$. Twenty microliters of probe hybridization solution was added. The slides were incubated at $37^{\circ} \mathrm{C}$ for $2 \mathrm{~h}$, and then washed with TBS containing $0.1 \%$ triton $\times 100$. For detection, blocking solution (normal rabbit serum diluted 1:5 in TBS, $3 \% \mathrm{w} / \mathrm{v}$ bovine serum albumin, $0.1 \% \mathrm{v} / \mathrm{v}$ triton $\times 100$ ) was added for $10 \mathrm{~min}$, followed by incubation with rabbit FITC/AP (alkaline phosphatase conjugated antibody to fluorescein isothiocyanate) for $30 \mathrm{~min}$. After washing in TBS and alkaline phosphatase substrate buffer, the slides were incubated overnight with a solution containing 1000 microliters of dilute enzyme substrate and alkaline phosphatase buffer to which was added 1 microliter of levamisole hydrochloride as an inhibitor. Following overnight incubation, slides were washed with water and counterstained with hematoxylin. With each batch of slides, a positive and a negative control slide were also run. The positive control slide was a known case of EBV-positive Hodgkin's lymphoma to which was added the specific EBER oligonucleotide probe. The negative control slide was another section of the same case of known EBV-positive Hodgkin's lymphoma to which was added a random probe consisting of a fluoresceinlabeled oligonucleotide cocktail. In addition, for each case studied two sections were used; the EBER oligonucleotide probe was added to one section, and the random probe was added to the other. Using this random probe as a negative background control alongside the EBV probe contributes to the validation of staining obtained by the EBV probe. If this negative control slide showed significant background staining in a particular case, the slide having the EBER probe was considered non-interpretable and the test was repeated for that particular case. Two pathologists interpreted the slides independently and a consensus was taken.

\section{Results}

Of the 30 patients, 18 were males and age ranged between 13 and 70 years with a mean age of 41.6 years. All patients were negative for human immunodeficiency virus (HIV) and did not have any other immunodeficiency states clinically All the lesions were supratentorial. Twenty-one lesions were solitary and one was multiple. Histology showed diffuse large cell lymphoma with monomorphic cells-two to three times the size of the lymphocyte with scant cytoplasm and large vesicular nuclei and prominent nucleoli. The cells were seen in diffuse sheets and around blood vessels, infiltrating the normal brain parenchyma [Figure 1a and inset]. Reticulin stain showed increase in reticulin fibers with splaying of reticulin around blood vessels [Figure 1b].

Immunohistochemistry with leucocyte common antigen (CD45) was positive in 27 (90\%) (Figure 1c), CD20 was positive in 25 (83\%) patients and CD3 was positive in 2 (7\%) All the 3 patients negative for CD45 were positive for CD20. Of the 2 patients positive for CD3, one patient with scattered cells with CD3 positivity was predominantly CD20 positive. In four patients both CD20 and CD3 were negative [Figure 1d, Figure 1e]. The type of lymphoma was B cell type - 25 (83.3\%), T cell type - 1 (3.3\%), and the remaining 4 (13.3\%) were unclassified [Table 1]. EBV 

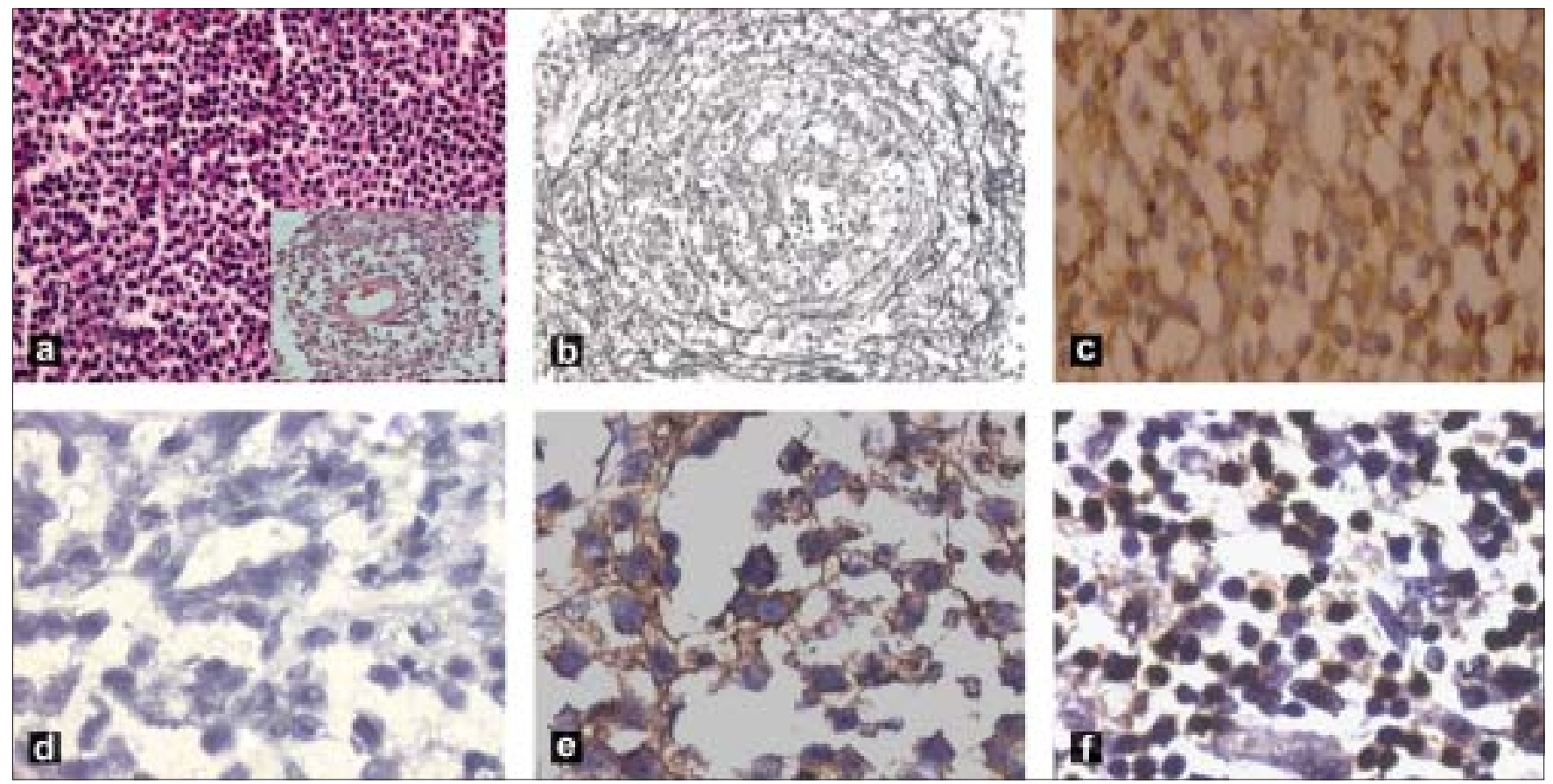

Figure 1: (a) Section showing monomorphic small round cell $(H$ and $E, \times 40$, inset showing perivascular lymphocytic cuffing); (b) Section showing splaying of reticulin fibers around vessel (reticulin original magnification $\times 10$ ); (c) Immunostaining with CD45 is positive in tumor cells (Strept.- ABC;

original magnification $\times 20$ ); (d) Immunostaining with CD20 showing membrane positivity in tumor cells (Strept.- ABC; original magnification $\times 40$ );

(e) Immunostaining with $\mathrm{CD} 3$ is negative in tumor cells (Strept.- ABC; original magnification $\times 10$ ); (f) Immunostaining with EBV LMP-1 showing strong cytoplasmic and membrane positivity in tumor cells (Strept.- ABC; original magnification $\times 40$ )

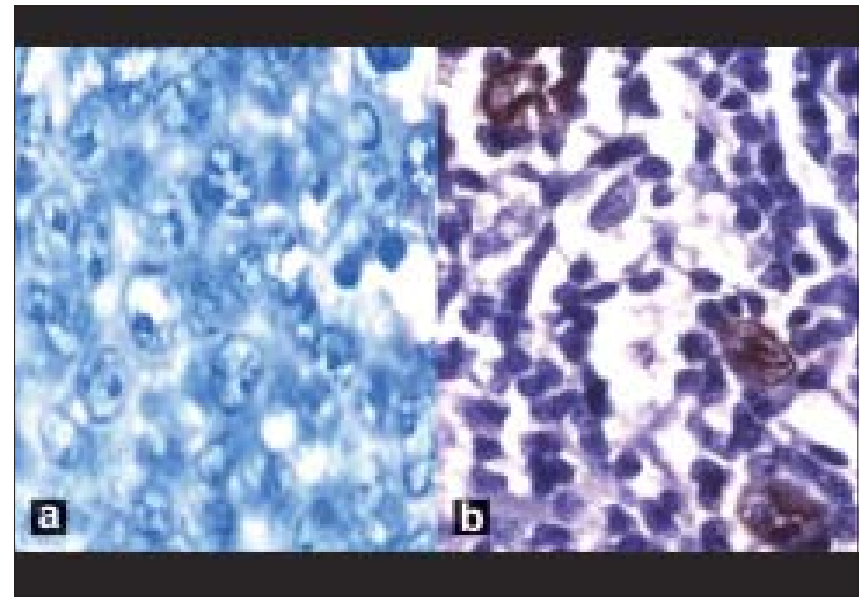

Figure 2: (a) In situ hybridization with EBER showing negativity in PCNSL, (b) positive signal is seen in Hodgkin's lymphoma (original magnification $\times 60$ )

\begin{tabular}{lcc}
\hline \multicolumn{3}{l}{ Table 1: Immunohistochemical profie of PC NSL } \\
\hline $\begin{array}{l}\text { Immunostains/ } \\
\text { In situ hybridization }\end{array}$ & Positive & Negative \\
\hline CD45 & & 03 \\
CD20 & 27 & 05 \\
CD3 & 25 & 28 \\
EBV LMP-1 & 02 & 06 \\
EBER (19) & 24 & $19 ;(4 / 19$ are both LMP-1 \\
& Nil & and EBER negative) \\
\hline
\end{tabular}

PCNSL: Primary central nervous system lymphoma, EBV LMP-1: Epstein barr virus latent membrane protein-1
LMP-1 showed membrane and cytoplasmic positivity in $24(80 \%)$ patients [Figure 1f]. All the 19 patients in whom ISH was done, were negative for EBER and 4 were negative for both LMP1 and EBER [Figure 2a, Figure 2b].

\section{Discussion}

In the present study all the patients were immunocompetent and younger in age, These observations are consistent with the earlier reports from India. ${ }^{[7,8]}$ Whereas in developed countries most of the PCNSL are in immunosuppressed individuals and the mean age at presentation is a decade later. ${ }^{[1,2,11]}$

EBV is a ubiquitous herpes virus and causative agent of infectious mononucleosis. ${ }^{[12]}$ It is associated with various malignancies like Burkitt's lymphoma, nasopharyngeal carcinoma, Hodgkin's lymphoma, peripheral T cell lymphoma, aggressive B cell lymphoma and AIDSassociated and post transplant lymphoproliferative disorders. ${ }^{[13-17]} \mathrm{EBV}$ LMP-1 is a latency protein that is implicated in the oncogenesis. In vitro overexpression of the LMP1 leads to morphological transformation to immortalize RAT-1 cell and immunogenesis in the nude mice. ${ }^{[18,19-21]}$ In EBV-associated lymphoproliferative disorders, LMP-1 is expressed in nasopharyngeal carcinoma and Hdogkin's lymphoma. ${ }^{[13,15]}$ Detection of LMP-1 lends support for the role of EBV in the 
pathogenesis of these tumors.

Immunosupressive state in patients with solid organ transplantation and HIV infection can predispose to EBV infection-related polyclonal lymphoproliferative disease that can develop into typical PCNSL. However, in immunocompetent individuals, the mechanism is uncertain. De Angelis et al., studied EBV in PCNSL by PCR technique and concluded that $85 \%$ of PCNSL in AIDS patients and 54\% in non-AIDS patients were associated with EBV infection. ${ }^{[22]}$ Camilleri-Boet et al., studied the status of EBV in 72 immunocompetent patients with PCNSL using ISH technique and concluded that PCNSL in immunocompetent patients is not associated with EBV infections. ${ }^{[6]}$ In an earlier study from India Rao et al., studied the association between EBV infection and PCNSL in immunocompetent patients using ISH technique and the results were negative for the association. They concluded that PCNSL in immunocompetent individuals has possibly a different pathogenetic mechanisms. ${ }^{[23]}$

The present study showed 80\% positivity for EBV LMP-1 with immunohistochemistry and 100\% negativity for EBER with ISH technique using specific oligonucleotide probe. EBV LMP-1 immunostains, are rapid, economical and can easily be performed in any laboratory when compared to ISH techniques. However immunostains can give false positive results. This can be due to poorl fixation of tissue and also immuno-staining being taken up by some of the brain tissues cells, and uninfected hematopoietic elements like eosinophils and plasma cells. ${ }^{[24-26]}$ No earlier study has used EBV LMP1 immunostaining to study the etiologic relationship between EBV and PCNSL. The false positive results with EBV LMP-1 in the present study were probably due to poor fixation of the tissue and immuno-staining being taken up by some of the brain tissue cells. These objervations suggests that ISH technique should be the technique of choice to study the causal relation between EBV and PCNSL. EBER detection by ISH is ideal for the histopathological detection of latent EBV in routine tissue specimens and combination of EBER and LMP-1 is more effective. ${ }^{[27,28]}$ However, EBV LMP-1 immunostain may not be appropriate for CNS tissue.

PCNSL has a very poor prognosis both in AIDS and immunocompetent individuals. The importance of finding the association between EBV and PCNSL is to explore the possibility of EBV-targeted therapy. Recently, a preclinical animal model for EBV positive PCNSL was developed which may be evaluated for new therapeutic approaches. ${ }^{[29]}$

\section{Acknowledgment}

The authors express sincere thanks to Dr. S.K. Shankar, Professor and Head, Department of Neuropathology, NIMHANS, Bangalore, Clementina Rama Rao, Associate Prof. Kidwai Memorial Institute of Oncology, Bangalore for their valuable suggestions, Mr. P Madhavan, Department of Pathology, Nizam's Institute of Medical Sciences, Hyderabad for technical support and to all neurosurgeons.

\section{References}

1. O’Neill BP, Illig JJ. Primary central nervous system lymphoma. Mayo Clin Proc 1989;64:1005-20.

2. DeAngelis LM. Primary central nervous system lymphoma as a secondary malignancy. Cancer 1991;67:431-5.

3. Birx DL, Redfield RR, Tosato G. Defective regulation of Epstein-Barr virus infection in patients with acquired immunodeficiency syndrome (AIDS) or AIDS-related disorders. N Engl J Med 1986;314:874-9.

4. Yau YH, O'Sullivan MG, Signorini D, Ironside JW, Whittle IR. Primary lymphoma of central nervous system in immunocompetent patients in south-east Scotland. Lancet 1996;348:890.

5. Camilleri-Broet S, Davi F, Feuillard J, Seilhean D, Michiels JF, Brousset P, et al. AIDS-related primary brain lymphomas: Histopathologic and immunohistochemical study of 51 cases. Hum Pathol 1997;28:367-74.

6. Camilleri-Broet S, Martin A, Moreau A, Angonin R, Henin D, Gontier MF, et al. Primary central nervous system lymphomas in 72 immunocompetent patients: Pathologic findings and clinical correlations. Am J Clin Pathol 1998;110:607-12.

7. Powari M, Radotra B, Das A, Banerjee AK. A study of primary central nervous system lymphoma in northern India. Surg Neurol $2002 ; 57: 113-6$.

8. Sarkar C, Sharma MC, Deb P, Singh R, Santosh V, Shankar SK. Primary central nervous system lymphoma: A hospital based study of incidence and clinicopathological features from India (1980-2003). J Neuro Oncol 2005;71:199-204.

9. Anagnostopoulos I, Hummel M. Epstein-Barr virus in tumours. Histopathology 1996;29:297-315.

10. Agarwal S, Ramanathan U, Naresh KN. Epstein-Barr virus association and ALK gene expression in anaplastic large-cell lymphoma. Hum Pathol 2002;33:146-52.

11. Alderson L, Fetell MR, Sisti M, Hochberg F, Cohen M, Louis DN. Sentinel lesions of primary CNS lymphoma. J Neurol Neurosurg Psychiatry 1996;60:102-5.

12. Niedobitek G, Agathanggelou A, Herbst H, Whitehead L, Wright DH, Young LS. Epstein-Barr virus (EBV) infection in infectious mononucleosis: Virus latency, replication and phenotype of EBV-infected cells. J Pathol 1997;182:151-9.

13. Epstein MA, Achong BG, Barr YM. Virus particles in cultured lymphoblasts from Burkitt's lymphoma. Lancet 1964;15:702-3.

14. Pallesen G, Hamilton-Dutoit SJ, Zhou X. The association of EpsteinBarr virus (EBV) with T cell lymphoproliferations and Hodgkin's disease: Two new developments in the EBV field. Adv Cancer Res 1993;62:79-239.

15. Pathmanathan R, Prasad U, Sadler R, Flynn K, Raab-Traub N. Clonal proliferations of cells infected with Epstein-Barr virus in preinvasive lesions related to nasopharyngeal carcinoma. N Engl J Med 1995;333:693-8.

16. Rea D, Delecluse HJ, Hamilton-Dutoit SJ, Marelle L, Joab I, Edelman L, et al. Epstein-Barr virus latent and replicative gene expression in post- transplant lymphoproliferative disorders and AIDSrelated non-Hodgkin's lymphomas. Ann Oncol 1994;5:113-6.

17. Glaser SL, Lin RJ, Stewart SL, Ambinder RF, Jarrett RF, Brousset P, et al. Epstein-Barr virus-associated Hodgkin's disease: Epidemiologic characteristies in international data. Int J Cancer 1997;70:375-82.

18. Wang D, Liebowitz D, Kieff E. An EBV membrane protein expressed in immortalized lymphocytes transforms established rodent cells. Cell $1985 ; 43: 831-40$. 
19. Wang D, Liebowitz D, Kieff E. An EBV membrane protein expressed in immortalized lymphocytes transforms established rodent cells. Cell 1985;43:831-40.

20. Johannsen E, Koh E, Mosialos G, Tong X, Kieff E, Grossman SR. Epstein-Barr virus nuclear protein 2 transactivation of the latent membrane protein 1 promoter is mediated by J kappa and PU.1. J Virol $1995 ; 69: 253-62$.

21. Kulwichit W, Edwards RH, Davenport EM, Baskar JF, Godfrey V, Raab-Traub N. Expression of the Epstein-Barr virus latent membrane protein 1 induces B cell lymphoma in transgenic mice. Proc Natl Acad Sci U S A 1998;95:11963-8.

22. DeAngelis LM, Wong E, Rosenblum M, Furneaux H. Epstein-Barr virus in acquired immune deficiency syndrome (AIDS) and non-AIDS primary central nervous system lymphoma. Cancer 1992;70:1607-11.

23. Rao CR, Jain K, Bhatia K, Laksmaiah KC, Shankar SK. Association of primary central nervous system lymphomas with the Epstein-Barr virus. Neurol India 2003;51:237-40.

24. Gulley ML. Molecular diagnosis of Epstein Barr virus - related diseases. J Mol Diagn 2001;3:1-10.

25. Jiwa NM, Oudejans JJ, Dukers DF, Vos W, Horstman A, van der Valk P, et al. Immunohistochemical demonstration of different latent membrane protein-1 epitopes of Epstein-Barr virus in lymphoproliferative diseases. J Clin Pathol 1995;48:438-42.
26. Hammer RD, Scott M, Shahab I, Casey TT, Cousar JB, Macon WR Latent membrane protein antibody reacts with normal hematopoietic precursor cells and leukemic blasts in tissues lacking Epstein-Barr virus genome by polymerase chain reaction. Am J Clin Pathol 1996;106:469-74.

27. Hamilton-Dutoit SJ, Raphael M, Audouin J, Diebold J, Lisse I, Pedersen C, et al. In situ demonstration of Epstein-Barr virus small RNAs (EBER 1) in acquired immunodeficiency syndrome-related lymphomas: Correlation with tumor morphology and primary site. Blood 1993;82:619-24

28. Gulley ML, Glaser SL, Craig FE, Borowitz M, Mann RB, Shema SJ, et al. Guidelines for interpreting EBER in situ hybridization and LMP1 immunohistochemical tests for detecting Epstein-Barr virus in Hodgkin lymphoma. Am J Clin Pathol 2002;117:259-67.

29. Roychowdhury S, Peng R, Baiocchi RA, Bhatt D, Vourganti S, Grecula J, et al. Experimental treatment of Epstein-Barr virusassociated primary central nervous system lymphoma. Cancer Res 2003;63:965-71.

Accepted on 08-02-2009

Source of Support: Nil, Conflict of Interest: None declared.

\section{Author Help: Online submission of the manuscripts}

Articles can be submitted online from http://ww w.journalonw eb.com. For online submission, the articles should be prepared in tw 0 files (first page file and article file). Images should be submitted separately.

\section{1) First Page File:}

Prepare the title page, covering letter, acknowledgement etc. using a word processor program. All information related to your identity should be included here. Use text/rtf/doc/pdf files. Do not zip the files.

2) Article File:

The main text of the article, beginning with the Abstract to References (including tables) should be in this file. Do not include any information (such as acknow ledgement, your names in page headers etc.) in this file. Use text/rtf/doc/pdf files. Do not zip the files. Limit the file size to $400 \mathrm{~kb}$. Do not incorporate images in the file. If file size is large, graphs can be submitted separately as images, without their being incorporated in the article file. This will reduce the size of the file.

3) Images:

Submit good quality color images. Each image should be less than $1024 \mathbf{~ k b ~ ( 1 ~ M ~ B ) ~ i n ~ s i z e . ~ T h e ~ s i z e ~ o f ~ t h e ~ i m a g e ~ c a n ~ b e ~ r e d u c e d ~ b y ~}$ decreasing the actual height and width of the images (keep up to about 6 inches and up to about 1200 pixels) or by reducing the quality of image. J PEG is the most suitable file format. The image quality should be good enough to judge the scientific value of the image. For the purpose of printing, always retain a good quality, high resolution image. This high resolution image should be sent to the editorial office at the time of sending a revised article.

4) Legends:

Legends for the figures/images should be included at the end of the article file. 